DOI

\title{
ОСОБЛИВОСТІ ОБМІНУ ВУГЛЕВОДНО-БІЛКОВИХ КОМПОНЕНТІВ СПОЛУЧНОЇ ТКАНИНИ ПАРОДОНТА ТА ЇХ ЦИТОКІНОВОЇ РЕГУЛЯЦІї У ХВОРИХ НА ВИРАЗКОВУ ХВОРОБУ ДВАНАДЦЯТИПАЛОЇ КИШКИ ЗАЛЕЖНО ВІД ВИДУ НЕЗНІМНИХ ЗУБНИХ ПРОТЕЗІВ

\author{
๑О. І. Рощук, О. Б. Бєліков, М. М. Сорохан \\ ВДНЗ України «Буковинський державний медичний університет»
}

РЕзЮМЕ. Мета роботи - встановити вплив незнімних металевих, металокерамічних та керамічних протезів на стан білково-вуглеводних компонентів сполучної тканини пародонта та стан їх цитокінової регуляції у крові хворих на виразкову хворобу (ВХ) дванадцятипалої кишки (ДПК).

Матеріали і методи. Обстежено 147 хворих на ВХ ДПК у фазі рубцювання виразки, у тому числі 43 особи із дефектами зубного ряду без зубних протезів (1 група), 35 осіб із незнімними металевими зубними протезами (2 група), 42 - із незнімними металокерамічними протезами (3 група), 27 - із незнімними керамічними протезами (4 група). Використовували клінічні, біохімічні та імуноферментні методи дослідження.

Результати досліджень. У хворих на ВХ ДПК без протезів зубного ряду виявлено істотні зміни метаболізму компонентів позаклітинного матриксу (ПКМ) пародонта: вірогідне зниження інтенсивності синтезу колагену, глікозаміногліканів, глікопротеїнів, фібронектину на тлі підвищення інтенсивності процесів колагенолізу та деградації фукоглікопротеїнів. Наявність металовмісних незнімних зубних протезів призвела до істотного поглиблення даного дисбалансу внаслідок підвищення активності колагеназ та еластази ПКМ, гіперпродукції прозапальних цитокінів (TNF-a, IL-1) та недостатності вмісту в крові факторів росту (TGF- $\beta_{1}$ ) анаболічної дії, які у сильній взаємозалежності корелюють із інтенсивністю реакцій ана-та катаболізму колагену, еластину, вмістом у крові глікозаміногліканів, фукоглікопротеїнів, фібронектину.

Висновки. Наявність металовмісних незнімних зубних протезів у хворих на ВХ ДПК сприяє зниженню синтезу колагену та підвищенню колагенолізу внаслідок зростання активності колагеназ та еластази ПКМ, що супроводжується вірогідно вищою гіперпродукцією прозапальних цитокінів (TNF-a, IL-1) на тлі недостатності вмісту в крові факторів росту (TGF-ß1), які істотно перевищують показники хворих на ВХ без зубних протезів та за наявності незнімних керамічних протезів.

КлючовІ СлОВА: виразкова хвороба дванадцятипалої кишки; незнімні зубні протези; сполучна тканина; цитокіни.

Вступ. Дані літератури останніх років вказують на високу частоту коморбідності ВХ ДПК і різноманітної стоматологічної патології, що призводить до втрати зубів [3, 4]. Цей процес зумовлений спільними анатомо-фізіологічними особливостями тканин пародонта і ДПК, механізмами нейрогуморальної регуляції метаболізму, наявністю змін мікробіоценозу та розвитку дисбіозу, особливо за умов проведення повторних курсів ерадикаційної терапії Н.pyloгу, що створюють передумови для залучення тканин пародонта в патологічний процес при ВХ ДПК і прогресуючої втрати зубів $[1,4]$. Патологія тканин пародонта діагностується у $92 \%$ хворих на ВX ДПК, в основному вона представлена генералізованим пародонтитом [4]. У попередніх наших дослідженнях доведена роль активації процесів пероксидного окиснення ліпідів (ПОЛ) та окиснювальної модифікації білків (ОМБ) в механізмах запалення тканин пародонта при ВХ ДПК, що поглиблюються за умов встановлення незнімних металовмісних зубних протезів (НМП), чому сприяло виснаження загальної та місцевої системи антиоксидантого захисту (АОЗ) та природних механізмів детоксикації [2]. Відома роль оксидативного стресу щодо впливу на механізми індукції запалення пародонтальних тканин, активації лізосомальних протеолітичних ферментів, цитокінового дисбалансу, прискорення апоптозу епітелію слизових оболонок (СО) як ШКТ, так і ротової порожнини, істотного дисбалансу генерації елементів сполучної тканини, які фіксують зубний ряд, що може прискорити втрату зубів [1, 3, 5-9]. Ситуація ускладнюється за умов встановлення НМП, які провокують процеси ПОЛ та ОМБ і сприяють посиленню усіх відомих ланок прогресування патологічних станів $[2,3]$. Тому логічним було 6 дослідити стан метаболізму компонентів позаклітинного матриксу (ПКМ) тканин пародонта у хворих на ВХ ДПК залежно від виду зубного протезування та стану цитокінової ланки регуляції запалення.

Мета дослідження - встановити вплив незнімних металевих, металокерамічних та керамічних протезів на стан білково-вуглеводних компонентів ПКМ пародонта та стан їх цитокінової регуляції у крові хворих на ВХ ДПК.

Матеріал і методи дослідження. Обстежено 147 хворих на ВХ ДПК, фаза рубцювання, у тому числі 43 хворих на ВX із дефектами зубного ряду без зубних протезів (1 група), 35 хворих на $\mathrm{BX}$ із незнімними металевими зубними протеза- 
Огляди літератури, оригінальні дослідження, погляд на проблему

ми (НМП) (2 група), 42 хворих на ВX із незнімними металокерамічними протезами (НМКП) (3 група), 27 хворих на BX із незнімними керамічними протезами (НКП) (4 група). Вік хворих склав $(52,5 \pm 4,3)$ роки. У контрольну групу увійшли 30 практично здорових осіб (ПЗО) цього ж віку.

Зміни метаболізму компонентів ПКМ визначали за вмістом у крові вільного (ВОП) та білковозв'язаного оксипроліну (БЗОП), глікозаміногліканів (ГАГ), гексозамінів (ГА), серомукоїдів (СМ), сіалових кислот (СК), фукози, не зв'язаної з білком (ФНБ), рівнем колагенолітичної активності плазми крові (КЛА) за інтенсивністю лізису азоколу. Вміст у крові цитокінів: фактора некрозу

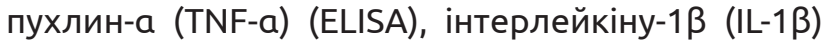
(Diaclon) та трансформуючого фактора росту- $\beta 1$ (TGF- $\beta_{1}$ ) (DRG), фібронектину, еластази (ЕЛ), металопротеїнази-1 (МMП-1) (DRG) визначали за допомогою імуноферментного аналізу. Статистичну обробку матеріалу проводили із використанням сучасних методів варіаційної статистики. Перед перевіркою статистичних гіпотез проведено аналіз нормальності розподілу величин у рандомізованих вибірках шляхом визначення коефіцієнтів асиметрії та ексцесу за допомогою критерію Хана-Шапіро-Уілкі. Вірогідність різниці середньої арифметичної та її похибки між групами дослідження визначали за допомогою двостороннього непарного t-критерію Стьюдента. Різницю вважали вірогідною при рівні значущості $\mathrm{p}<0,05$. t-критерій Стьюдента застосовували лише в разі нормального розподілу за рівності генеральних дисперсій вибірок, що порівнювалися, яку переві- ряли за допомогою F-критерію Фішера. B інших випадках для порівняння отриманих результатів використовували непараметричний ранговий критерій Манна-Уітні. Кореляційний аналіз проводили шляхом визначення лінійного параметричного коефіцієнта кореляції Пірсона та непараметричного коефіцієнта кореляції рангів Спірмена. Математичну обробку отриманих даних проводили на комп'ютері на базі процесора AMD Athlon 64 за допомогою програми Рrimer of Biostatistics. Version 4.03.

Результати й обговорення. Одним із проявів структурних порушень ПКМ пародонта та стінки ДПК у хворих на ВX із дефектами зубних рядів без зубних протезів $\epsilon$ встановлене нами пригнічення синтезу колагену, показником якого $є$ зменшення вмісту БЗОП у сироватці крові у 1,4 раза $(p<0,05)$ (табл. 1). Істотніші зміни метаболізму колагену були зумовлені наявністю НМП (зменшення у 1,9 раза, $\mathrm{p}<0,01$ ) та НМКП (зменшення у 1,8 раза, p<0,01). У хворих на ВХ із наявністю НКП встановлено вірогідне зменшення вмісту в крові БЗОП у $1,4$ раза, порівняно з ПЗО ( $<<0,01)$, що знаходиться на рівні показника у хворих 1 групи $(p>0,05)$ (див. табл. 1). Зміни синтезу колагенових білків при ВХ, ймовірно, зводяться до сповільнення процесингу та зниження кількості синтезованого колагену, насамперед I, III та IV типів, можливо, генетично зумовлених $[6,7]$. Водночас показник вмісту в крові ВОП (табл. 1), який є біохімічним маркером катаболізму колагену, у хворих 1 групи у 1,3 раза, 2 та 3 груп - у 1,5 раза, у хворих 4 групи - у 1,2 раза $\left(p_{1-4}<0,05\right)$ перевищував показник у

Таблиця 1. Показники обміну компонентів сполучної тканини у хворих на виразкову хворобу ДПК залежно від виду незнімних протезів дефектів зубного ряду $(\mathrm{M} \pm \mathrm{m})$

\begin{tabular}{|c|c|c|c|c|c|}
\hline \multirow[b]{2}{*}{ Показник } & \multirow[b]{2}{*}{ ПЗО, n=30 } & \multicolumn{4}{|c|}{ Групи обстежених хворих } \\
\hline & & $\begin{array}{c}\text { ВX (група 1), } \\
\mathrm{n}=43\end{array}$ & $\begin{array}{c}\text { ВХ із НМП } \\
\text { (група 2), n=35 }\end{array}$ & $\begin{array}{c}\text { ВХ із НМКП } \\
\text { (група 3), } n=42\end{array}$ & $\begin{array}{c}\text { ВХ із НКП } \\
\text { (група 4), } n=27\end{array}$ \\
\hline БЗОП, мкмоль/л & $41,3 \pm 3,6$ & $30,2 \pm 1,5$ * & $21,2 \pm 1,2 * / * *$ & $23,5 \pm 1,3 * / * *$ & $29,7 \pm 1,1 * / * * * / \#$ \\
\hline ВОП, мКмоль/л & $12,3 \pm 0,03$ & $15,7 \pm 0,3$ * & $18,2 \pm 0,7 * / * *$ & $17,9 \pm 0,6 * / * *$ & $14,6 \pm 0,3 * / * * * \#$ \\
\hline ГАГ, мкмоль/л & $98,4 \pm 1,7$ & $72,2 \pm 1,9$ * & $62,7 \pm 2,3 * / * *$ & $64,3 \pm 1,4 * / * *$ & $71,5 \pm 2,1 * / * * * / \#$ \\
\hline ГА, ммоль/л & $5,5 \pm 0,02$ & $4,9 \pm 0,03$ * & $3,4 \pm 0,1 * / * *$ & $3,8 \pm 0,2 * / * *$ & $4,9 \pm 0,2 * / * * * / \#$ \\
\hline СК, ммоль/л & $2,1 \pm 0,01$ & $1,8 \pm 0,07$ * & $1,5 \pm 0,03 * / * *$ & $1,7 \pm 0,02 * / * * *$ & $1,8 \pm 0,04 * / * * *$ \\
\hline ФНБ, мКмоль/л & $37,2 \pm 5,7$ & $60,3 \pm 3,2$ * & $81,8 \pm 4,1 * / * *$ & $75,5 \pm 3,8 * / * *$ & $63,1 \pm 3,5 * / * * *$ \\
\hline $\begin{array}{l}\text { Фібронектин, } \\
\text { мкг/мл }\end{array}$ & $334,9 \pm 12,3$ & $285,2 \pm 10,9$ * & $201,2 \pm 15,6 * / * *$ & $207,3 \pm 11,5 * / * *$ & $\begin{array}{c}270,1 \pm 14,1 \\
* / * * * / \#\end{array}$ \\
\hline $\begin{array}{l}\text { КЛА, мкмоль/ } \\
\text { лхгод. }\end{array}$ & $2,5 \pm 0,01$ & $5,6 \pm 0,01$ * & $7,9 \pm 0,004 * / * *$ & $7,4 \pm 0,01 * / * * / * * *$ & $\begin{array}{c}5,9 \pm 0,003 \\
* / * * / * * * / \#\end{array}$ \\
\hline ММП-1, мКг/л & $8,2 \pm 0,5$ & $10,3 \pm 0,3$ * & $12,5 \pm 0,4 * / * *$ & $10,1 \pm 0,3 * / * * *$ & $9,7 \pm 0,2 * / * * *$ \\
\hline Еластаза, нг/мл & $152,5 \pm 1,8$ & $172,8 \pm 2,5$ * & $188,9 \pm 1,4 * / * *$ & $183,2 \pm 1,2 * / * *$ & $169,5 \pm 1,9 * / * * * / \#$ \\
\hline
\end{tabular}

Примітка: * - різниця вірогідна у порівнянні з показником у ПзО ( $<0,05)$;

** - різниця вірогідна у порівнянні з показником у хворих на BX 1 групи $(p<0,05)$;

*** - різниця вірогідна у порівнянні з показником у хворих на BX 2 групи $(p<, 05)$;

\# -різниця вірогідна у порівнянні з показником у хворих на BX 3 групи $(p<0,05)$. 
Огляди літератури, оригінальні дослідження, погляд на проблему

ПЗО. Підсилення деструктивних процесів у СО ДПК та тканинах пародонта може бути зумовлено Встановленим нами зростанням КЛА плазми крові, максимально вираженим при ВХ за наявності НМП - у 3,3 раза $(p<0,05)$ та НМКП - зростання у 3,0 рази $(p<0,05)$. У хворих на ВX (1 та 4 групи) КЛА крові була вищою від ПЗО відповідно у 2,2 та 2,4 раза $\left(\mathrm{p}_{1,4}<0,05\right)$. Цьому сприяло вірогідне зростання активності ММП-1 плазми крові: у 1 групі на 25,6 \% від контролю, у 2 групі - на 52,4 \%, у 3 групі - на $23,2 \%$, у 4 групі - на $18,3 \%\left(\mathrm{p}_{1-4}<0,05\right)$.

Водночас у хворих на ВХ зростання сумарної КЛА крові можна пояснити виявленим нами підвищенням активності еластази крові у порівнянні з показником у ПЗО: відповідно у хворих 1 групи - на 13,7 \%, 2 групи - на 24,3 \%, 3 групи - на 20,5\%, 4 групи - на $11,5 \%\left(p_{1-4}<0,05\right)$ (див. табл. 1), що свідчить про активацію системи протеолітичного розщеплення структурних білків ПКМ та створення умов для втрати зубів у хворих на BX.

Враховуючи функціональну роль протеогліканів та глікопротеїнів у забезпеченні структурної цілісності ПКМ [5], дослідження вмісту у крові ГАГ виявило під час активної фази ВX із дефектами зубів без протезів, а також за наявності незнімних протезів, зменшення їх вмісту в крові. Зокрема, у хворих 1 групи встановлено зниження вмісту ГАГ у 1,4 раза від контролю, у 2 групі - у 1,6 раза, у 3 групі - у 1,5 раза, у 4 групі - у 1,4 раза $\left(p_{1-4}<0,05\right)$. Вміст у крові ГА також був знижений на $10,9 \%$, $38,2 \%, 30,9 \%$ та 10,9 \% відповідно у хворих $1-4$ груп порівняння $\left(\mathrm{p}_{1-4}<0,05\right)$. Дослідження вмісту СК у крові також показало їх вірогідне зменшення: відповідно у хворих 1, 3, 4 груп - у 1,2 раза, у хворих 2 групи - у 1,4 раза $\left(p_{1-4}<0,05\right)$, що, ймовірно, може свідчити про збіднення СО ДПК вищезазначеними компонентами ПКМ внаслідок зменшення їх синтезу.

Одним із важливих глікопротеїнів тканин пародонта та кісткової тканини $є$ фібронектин $[5,6]$. Фібронектин синтезується клітинами та секретується в міжклітинний простір. Він має властивості «липкого» білка. Зв'язуючись з вуглеводними групами сіалогліколіпідів на поверхні плазматичних мембран, він забезпечує взаємодію клітин між собою та компонентами міжклітинного матриксу. Взаємодіючи з колагеновими фібрилами, фібронектин забезпечує утворення ПКМ [5-7]. Аналіз змін фібронектину у хворих на ВХ вказує на вірогідне зниження його вмісту у крові як при ВX без встановлених НП, так і за наявності НП різного гатунку. Зокрема, у 1 групі хворих встановлено зниження вмісту фібронектину у 1,2 раза від контролю, у 2 групі - у 1,7 раза, у 3 групі - у 1,6 раза, у 4 групі-у 1,2 раза ( $\left.p_{1-4}<0,05\right)$ (табл. 1). Нами встановлена кореляційна залежність між вмістом фібро- нектину та концентрацією ГАГ, $Г А ~(r=0,63, r=0,51$, $p<0,05)$, ВОП, ФНБ ( $r=-0,57, p<0,05 ; r=-0,52, p<0,01)$. Ці кореляційні зв'язки свідчать про важливість фібронектину для процесів синтезу колагену, протеогліканів та глікопротеїнів за пригнічувального впливу його на катаболічні процеси в ПКМ.

Показники вмісту ФНБ у хворих на ВХ усіх груп порівняння вірогідно зростали (табл. 1), із максимальним збільшенням у хворих 2 групи порівняння (у 2,2 раза, $p<0,05)$, і перевищували за інтенсивністю зростання показники у ПзО: відповідно у 1,6 раза, 2,2 раза, 2,0 та 1,7 раза $\left(p_{1-4}<0,05\right)$ (див. табл. 1). Виявлений нами значний прямий кореляційний зв'язок між концентрацією ФНБ та КЛА плазми крові $(r=0,55-0,61, p<0,001)$ може свідчити про те, що ММП, поряд з розпадом колагену, інтенсифікують процеси катаболізму фукоглікопротеїнів. Отже, виявлене нами збільшення вмісту ФНБ у сироватці крові, очевидно, можна пояснити прискоренням деградації фукоглікопротеїнів та руйнуванням клітин не лише СО ДПК, але і ПКМ тканин пародонта. Джерелом ФНБ сироватки крові, як відомо, можуть також бути церулоплазмін, імуноглобуліни, частина групоспецифічних речовин крові, глікопротеїни слизу і лізосом клітин, а також фуколіпіди і компоненти рецепторів біомембран $[4,5,7]$. Підвищена деградація білкових та глікопротеїнових комплексів ПКМ у хворих на ВХ поглиблюється у зв'язку із впливом сплавів металів, що входять до складу НМП.

3 метою встановлення ролі прозапальних цитокінів у розвитку та прогресуванні розладів ПКМ у хворих на ВX із дефектами зубних рядів було проведено кореляційний аналіз між вмістом в крові низки цитокінів та маркерами інтенсивності продукції та деградації ПКМ. Аналіз результатів дослідження цитокінового профілю крові показав, що в усіх групах хворих встановлено вірогідне підвищення вмісту в крові прозапальних цитокінів (табл. 2): TNF-a, IL-1 та зниження вмісту TGF- $\beta_{1}$. Зокрема, вміст TGF- $\beta_{1}$ у хворих 2-3 груп був нижчим від показника у ПЗО у 2,3 раза $\left(\mathrm{p}_{2,3}<0,05\right)$, а у хворих 1 групи мав тенденцію до зниження ( $p>0,05)$.

Вміст у крові TNF-a у хворих 1 групи перевищував показник у ПЗО у 2,0 рази, 2+3 групах - у 2,5 раза $\left(\mathrm{p}_{1,2+3}<0,05\right)$, із наявністю вірогідної міжгрупової різниці $(p<0,05)$. Останній факт свідчить про патогенетичну роль незнімного протезування металевими протезами у механізмах ураження тканин пародонта у хворих на ВX. Вміст у крові IL-1 $\beta$ у хворих 1 групи перевищував показник у групі ПЗО у 3,2 раза, у хворих 2+3 груп - у 3,8 раза $\left(p_{1-2,3}<0,05\right)$, із відсутністю вірогідної міжгрупової різниці у групах 1 та $2+3$ (р>0,05). Встановлений 
Огляди літератури, оригінальні дослідження, погляд на проблему

Таблиця 2. Вміст у крові прозапальних цитокінів та трансформуючого фактора росту $\beta 1$ у хворих на виразкову хворобу ДПК залежно від наявності незнімних металовмісних протезів (M士m)

\begin{tabular}{|c|c|c|c|}
\hline \multirow{2}{*}{ Показник } & \multirow{2}{*}{ П3О, n=20 } & \multicolumn{2}{|c|}{ Групи обстежених хворих } \\
\hline & & ВX (група 1), n=18 & ВХ з НМП (група 2+3), n=25 \\
\hline TGFß, пг/мл & $18,2 \pm 2,0$ & $16,0 \pm 2,3$ & $8,6 \pm 1,2 * / * *$ \\
\hline TNFa, пг/мл & $15,1 \pm 3,4$ & $31,8 \pm 1,1$ * & $37,1 \pm 1,3 * / * *$ \\
\hline $\mathrm{IL}-1_{\beta}$, пг/Мл & $13,9 \pm 4,5$ & $45,1 \pm 2,7$ * & $52,7 \pm 3,5$ * \\
\hline
\end{tabular}

Примітка.

* - різниця вірогідна у порівнянні з показником у ПзО $(\mathrm{P}<0,05)$;

** - різниця вірогідна у порівнянні з показником у хворих 1 групи $(P<0,05)$.

значний ступінь цитокінового дисбалансу у щільній взаємозалежності корелює із основними компонентами ПКМ у хворих на ВХ. Зокрема, встановлено кореляційний зв'язок між вмістом у крові TNF-a, TGF- $\beta_{1}$ та Б3ОП ( $r=-0,63 ; r=0,52(p<0,05)$ відповідно), вмістом у крові TNF-a, TGF- $\beta_{1}$ та ВОП (відповідно $r=0,68 ; r=-0,67(p<0,05))$, який свідчить про високу активність процесів катаболізму колагену та низьку активність колагеногенезу у цього контингенту хворих; між вмістом у крові TNF-a, TGF- $\beta_{1}$ та рівнем $Г A(r=-0,45 ; r=0,49(p<0,05))$; вмістом IL-1, TGF- $\beta_{1}$ та ГАГ (відповідно $r=-0,59 ; r=0,46$ $(p<0,05))$, вмістом IL-1 та CK $(r=-0,42(p<0,05))$; вмістом TGF- $\beta$, TNF- $a$, IL-1 $\beta$ та ФНБ ( $r=-0,58 ; r=0,63$ та $r=0,71$ ( $p<0,05)$ відповідно); вмістом TNF-a, IL-1 та церулоплазміну $(r=0,55 ; r=0,47(p<0,05)$ відповідно); вмістом в крові TGF- $\beta_{1}$, TNF-a, IL-1 та вмістом в крові фібронектину $(r=0,78 ; \quad r=-0,64 ; \quad r=-0,72$ $(p<0,05))$, а також кореляційний зв'язок високої сили між показниками вмісту в крові TGF- $\beta_{1}$, TNF-a, IL-1 та активністю ММП-1 ( $r=-0,81 ; r=0,78$; $r=0,72(p<0,05)$ відповідно). Таким чином, індукція деградації ПКМ під впливом прозапальних цито- кінів та зниження його синтезу внаслідок недостатності факторів росту $\epsilon$ одним із механізмів ураження тканин пародонта у хворих на ВX, а також подальшого їх пошкодження внаслідок негативного впливу металовмісних протезів.

Висновки. Наявність металевих та металокерамічних незнімних зубних протезів у хворих на ВХ ДПК на тлі вірогідного зниження синтезу глікозаміногліканів, глікопротеїнів, фібронектину, підвищеної деградації фукоглікопротеїнів, сприяє істотному зниженню синтезу колагену, підвищенню активності колагеназ та еластази, що супроводжується гіперпродукцією прозапальних цитокінів (TNF-a, IL-1) на тлі недостатності вмісту в крові факторів росту (TGF- $\beta 1)$, які істотно перевищують показники у хворих на ВХ без зубних протезів та за наявності незнімних керамічних протезів.

Перспективи подальших досліджень - вивчення ймовірного впливу стабілізаторів сполучної тканини на показники метаболізму компонентів ПКМ у хворих на ВХ ДПК, які користуються незнімними металовмісними протезами.

\section{ЛІТЕРАТУРА}

1. Барінов Е. Ф. Функціональна активність та роль міофібробластів у реалізації компенсаторно-пристосувальних процесів у гастродуоденальній зоні / Е. Ф. Барінов, О. М. Сулаєва // Сучасна гастроентерол. - 2011. - № 1. - С. 103-110.

2. Бєліков О. Б. Стан оксидантно-протиоксидантного гомеостазу та інтенсивність нітрозитивного стресу у хворих на кислотозалежні захворювання шлунково-кишкового тракту залежно від виду зубного протезування / О. Б. Бєліков, О. І. Рощук // Вісник проблем біології і медицини. - 2014. - Вип. 2, Т. 1 (107). - С. 66-69.

3. Клініко-морфологічні зміни слизової оболонки порожнини рота щурів при місцевому одноразовому застосуванні пластикостимуляторів на основі сполук природного походження / В. М. Зубачик, І. О. Іськів, І. В. Ган, А. М. Ященко // Світ медицини та біології. - 2013. - № 2. - C. 34-38.

4. ЛукиныхЛ.М.Хронический генерализованный пародонтит. Часть І. Современный взгляд на этиологию и патогенез / Л. М. Лукиных, Н. В. Круглова // Стоматология. - 2011. - № 1. - С. 123-125.

5. Сучасні підходи до діагностики та лікування гастроезофагеальної рефлюксної хвороби та гастропатій у хворих на хронічне обструктивне захворювання легень та цукровий діабет / М. Ю. Коломоєць, О. С. Хухліна, І. В. Дудка [та ін.] : методичні рекомендації МОЗ України.-Київ, 2008. - 32 с.

6. Федів О. І. Роль цитокінів у порушенні обміну вуглеводно-білкових компонентів позаклітинного матриксу при виразковій хворобі шлунка і дванадцятипалої кишки / О. І. Федів, М. Ю. Коломоєць // Лікарська справа (Врачебное дело). - 2001. - № 4. - С. 181-182.

7. Федів О. І. Стан сполучної тканини у хворих на виразкову хворобу з супутнім ураженням гепатобіліар- 
Огляди літератури, оригінальні дослідження, погляд на проблему

ної системи в динаміці лікування препаратом «Ербісол» / О. І. Федів // Бук. мед. вісник. -2000. -Т. 4, № 2. -С. 127-132.

8. Brenmoehl J. Transforming growth factor-beta 1 induces intestinal myofibroblast differentiation and modulates their migration / J. Brenmoehl, S. N. Miller //
World J. Gastroenterol. - 2009. - P. 1431-1442.

9. Playford R. J. Cytokines and growth factor modulators in intestinal inflammation and repair / R. J. Playford, S. Ghosh // J. Pathol. - 2005. - Vol. 250. - P. 417-425.

\title{
REFERENCES
}

1. Barinov, E.F., \& Sulayeva, O.M. (2011). Funktsionalna aktyvnist ta rol miofibroblastivu realizatsii kompensatornoprystosuvalnykh protsesiv u hastroduodenalniy zoni [The functional activity and the role of myofibroblasts in the implementation of compensatory-adaptive processes in gastroduodenal zone]. Suchasna gastroenterol. - Modern Gastroenterology, 1, 103-110 [in Ukrainian].

2. Belikov, O.B., \& Roshchuk, O.I. (2014). Stan oksydantno-protyoksydantnoho homeostazu ta intensyvnist nitrozytyvnoho stresu u khvorykh na kyslotozalezhni zakhvoriuvannia shlunkovo-kyshkovoho traktu zalezhno vid vydu zubnoho protezuvannia [State of oxidant and antioxidant homeostasis and nitrositive stress intensity in patients with acid dependent diseases of gastro-intestinal tract, depending on the type of dental prosthetics]. Visnyk problem biolohii i medytsyny - Journal of Problems of Biology and Medicine, 2 (107), 66-69 [in Ukrainian].

3. Zubachyk, V.M., Iskiv, M.O., Han, I.V., \& Yashchenko, A.M. (2013). Kliniko-morfolohichni zminy slyzovoi obolonky porozhnyny rota shchuriv pry mistsevomu odnorazovomu zastosuvanni plastykostymuliatoriv na osnovi spoluk pryrodnoho pokhodzhennia [Clinical and morphological changes of the oral mucosa of rats in the local plastic stimulators based on compounds of natural origin]. Svit medytsyny ta biolohii - World of Medicine and Biology, 2, 34-38. [in Ukrainian].

4. Lukinykh, L.M., \& Kruglova, N.V. (2011). Khronycheskiy generalizovannyi parodontyt Chast I. Sovremenyi vzgliad na etiologiyu i patogenez [Chronic generalized periodontitis. Part I. Modern view of the etiology and pathogenesis]. Stomatologiya - Stomatology, 1,123-125 [in Russian].

5. Kolomoyets, M.Yu., Khukhlina, O.S., \& Dudka, I.V. (2008). Suchasni pidkhody do diahnostyky ta likuvannia hastroezofahealnoi refliuksnoyi khvoroby ta hastropatiy u khvorykh na khronichne obstruktyvne zakhvoriuvannia lehen ta tsukrovyi diabet [Current approaches to diagnosis and treatment of gastroesophageal reflux disease and gastropathy in patients with chronic obstructive pulmonary disease and diabetes]. Metodychni rekomendatsii MOZ Ukrayiny - Metodychni Rekomendatsii $\mathrm{MOH}$ of Ukraine [in Ukrainian].

6. Fediv, O.I., \& Kolomoyets, M.Yu. (2001). Rol tsytokiniv u porushenni obminu vuhlevodno-bilkovykh komponentiv pozaklitynnoho matryksu pry vyrazkoviy khvorobi shlunka i dvanadtsyatypaloi kyshky [The role of cytokines in the metabolism of carbohydrate-protein components of the extracellular matrix gastric ulcer and duodenal ulcer]. Likarska sprava - Doctor Business, 4, 181182 [in Ukrainian].

7. Fediv O.I. (2000). Stan spoluchnoi tkanyny u khvorykh na vyrazkovu khvorobu z suputnim urazhenniam hepatobiliarnoi systemy $v$ dynamitsi likuvannia preparatom "Erbisol" [State of connective tissue in ulcer patients with concomitant lesions of the hepatobiliary system dynamics drug treatment "Erbisol"]. Buk. med. Visnyk - Bukovynian Medical Journal, 4 (2), 127-132 [in Ukrainian].

8. Brenmoehl, J., \& Miller, S.N. (2009). Transforming growth factor-beta 1 induces intestinal myofibroblast differentiation and modulates their migration. World $\mathrm{J}$. Gastroenterol., 1431-1442. doi: 10.3748/wjg.15.1431.

9. Playford, R.J., \& Ghosh, S. (2005) Cytokines and growth factor modulators in intestinal inflammation and repair. J. Pathol., 250, 417-425. doi: 10.1002/path.1722.

\section{ОСОБЕННОСТИ ОБМЕНА УГЛЕВОДНО-БЕЛКОВЫХ КОМПОНЕНТОВ СОЕДИНИТЕЛЬНОЙ ТКАНИ ПАРОДОНТА И ИХ ЦИТОКИНОВОЙ РЕГУЛЯЦИИ У БОЛЬНЫХ ЯЗВЕННОЙ БОЛЕЗНЬЮ ДВЕНАДЦАТИПЕРСТНОЙ КИШКИ В ЗАВИСИМОСТИ ОТ ВИДА НЕСЪЕМНЫХ ЗУБНЫХ ПРОТЕЗОВ}

\author{
๑А. И. Рощук, А. Б. Беликов, Н. Н. Сорохан
}

ВГУз Украины «Буковинский государственный медицинский университет»

РЕЗЮМЕ. Цель работы - установить влияние несъемных металлических, металлокерамических и керамических протезов на сосотояние белково-углеводных компонентов соединительной ткани пародонта и состояние их цитокиновой регуляции у больных язвенной болезнью (ЯБ) дванадцятиперстной кишки (ДПК). 
Огляди літератури, оригінальні дослідження, погляд на проблему

Материалы и методы. Обследованы 147 больных ЯБ ДПК в фазе рубцевания язвы, в том числе: 43 пациента с дефектами зубного ряда без зубных протезов (1 группа), 35 лиц с несъемными металлическими протезами (2 группа), 42 - с несъемными металлокерамическими протезами (3 группа), 27 - с несъемными керамическими протезами (4 группа). Испольовали современные клинические, биохимические и иммуноферментные методы исследования.

Результаты исследований. У больных ЯБ ДПК без протезов зубного ряда установлены существенные нарушения метаболизма компонентов внеклеточного матрикса (ВКМ) пародонта: достоверное снижение интенсивности синтеза коллагена, гликозаминогликанов, гликопротеинов, фибронектина на фоне повышения интенсивности процессов коллагенолиза и деградации фукогликопротеинов. Наличие металлосодержащих несъемных зубных протезов привело к существенному усугублению данного дисбаланса вследствие активации коллагеназ и элластазы BKM, гиперпродукции провоспалительных цитокинов (TNF-a, IL-1), недостаточности содержания в крови факторов роста (TGF- $\left.\beta_{1}\right)$ анаболического дейстивия, которые в сильной взаимозависимости коррелируют с интенсивностью реакций ана- и катаболизма коллагена, элластина, содержанием в крови гликозаминогликанов, фукогликопротеинов, фибронектина.

Выводы. Наличие металлосодержащих несъемных зубных протезов у больных ЯБ ДПК способствует торможению синтеза коллагена, повышению коллагенолиза вследствие активации коллагеназ и элластазы BKM, что сопровождается достоверной гиперпродукцией провоспалительных цитокинов (TNF-a, IL-1) на фоне дефицита факторов роста (TGF-ß1), которые превышают показатели у больных ЯБ без зубных протезов и с наличием несъемных керамических протезов.

КЛючЕВЫЕ слОВА: язвенная болезнь двенадцатиперстной кишки; несъемные зубные протезы; соединительная ткань; цитокины.

\title{
PECULIARITIES OF PERIODONTAL CARBOHYDRATE-PROTEIN OF CONNECTIVE TISSUE COMPONENTS METABOLISM AND ITS CYTOKINE REGULATION IN PATIENTS WITH DUODENAL ULCER DEPENDING ON THE TYPE OF FIXED DENTURES
}

\author{
๑O. I. Roshchuk, O. B. Belikov, N. N. Sorokhan \\ Bukovynian State Medical University
}

SUMMARY. The aim of the work - to determine the influence of fixed metal, metal-ceramic and ceramic dentures on the state of protein and carbohydrate components of periodontal connective tissue and their cytokine regulation in patients with duodenum ulcer (DPU).

Materials and Methods. 147 patients with duodenal ulcer were examined using modern clinical, biochemical and immunoenzyme methods, including 43 persons with edentulous spaces without dentures (group 1), 35 people with fixed metal dentures (group 2), 42 patients with ulcer with fixed metal-ceramic dentures ( 3 group), 27 patients with fixed ceramic dentures (group 4).

Results. In patients with DU without denture a significant changes in metabolism of the periodontal extracellular matrix (ECM) components were established, likely reducing the intensity of the synthesis of collagen, glycosaminoglycans, glycoproteins and fibronectin on the background of increasing the intensity of collagenolysis and fukoglycoproteins degradation. The presence of metal fixed dentures leads to a substantial deepening of imbalances due to increased activity of collagenase and elastase of ECM, overproduction of proinflammatory cytokines (TNF-a, IL-1) and failure of growth factors (TGF- $\beta 1$ ) with anabolic action in the blood, which have a strong correlation with the intensity of reactions ana- and catabolism of collagen, elastin, blood levels of glycosaminoglycans, fukoglycoproteins, fibronectin content.

Conclusions. The presence of metal fixed dentures in patients with DPU reduces collagen synthesis and increases collagenolytic activity of plasma due to increased activity of collagenase and elastase of ECM, accompanied by hyperproduction of proinflammatory cytokines (TNF- $a, \mathrm{IL}-1$ ) against the deficiency of blood growth factors (TGF- $\beta 1$ ) content, which were significantly higher in comparison with patients with DPU without dentures and in patients with fixed ceramic dentures.

KEY WORDS: duodenal ulcer; fixed metal dentures; connective tissue; cytokines. 